\title{
Soil factors affecting solubility and mobility of zinc in contaminated soils
}

\author{
B. Rutkowska • W. Szulc • K. Bomze • \\ D. Gozdowski $\cdot$ E. Spychaj-Fabisiak
}

Received: 24 May 2013/Revised: 20 August 2013/ Accepted: 13 March 2014/Published online: 9 April 2014

(C) Islamic Azad University (IAU) 2014

\begin{abstract}
In view of modern worldwide research carried out in the context of broadly understood soil chemistry and monitoring of the natural environment, the methods of assessing the risk of $\mathrm{Zn}$ contamination in soil and agricultural crops based on the analyses of $\mathrm{Zn}$ concentration in the soil solution have gained more recognition. Accordingly, research on the evaluation of the effects of selected soil properties on changes in solid/solution partitioning coefficient $\left(K_{\mathrm{d}}\right)$, the total concentration and activity of zinc in the soil solution was undertaken in this study. The study was based on the microplot field experiment. Investigated soil factors were as follows: soil texture, $\mathrm{pH}$, organic carbon content and the degree of $\mathrm{Zn}$ contamination. The results indicated that zinc activity in the soil solutions was very high and comparable to the total concentration of zinc. The investigated soil properties significantly influenced the $K_{\mathrm{d}}$, the total concentration of zinc, as well as the concentration of $\mathrm{Zn}^{2+}$ in the soil solution. The total concentration and activity of zinc in the soil solution increased with increasing $\mathrm{Zn}$ content in the soil and rising soil acidity,
\end{abstract}

B. Rutkowska $(\bowtie) \cdot$ W. Szulc $\cdot$ K. Bomze

Department of Agricultural Chemistry, Faculty of Agriculture and Biology, Warsaw University of Life Sciences-SGGW, Nowoursynowska 159, 02-776 Warsaw, Poland

e-mail: beata_rutkowska@sggw.pl

\section{Gozdowski}

Department of Experimental Design and Bioinformatics, Faculty of Agriculture and Biology, Warsaw University of Life Sciences-SGGW, Nowoursynowska 159, 02-776 Warsaw, Poland

E. Spychaj-Fabisiak

Department of Agricultural Chemistry, Faculty of Agriculture and Biotechnology, University of Technology and Life Sciences in Bydgoszcz, Bernardyńska 6, 85-029 Bydgoszcz, Poland while they decreased with increasing the content of organic carbon and clay particles. The values of $K_{\mathrm{d}}$ increased significantly with rising soil $\mathrm{pH}$ and total $\mathrm{Zn}$ content and decreased with increasing soil organic content. Observed $K_{\mathrm{d}}$ values were significantly higher in soil with $13 \%$ clay than in soil with $7 \%$ clay.

Keywords Soil properties - Soil solution - Zinc activity · Zinc concentration

\section{Introduction}

The accumulation of heavy metals in soil is of interest because of the adverse affect heavy metals may pose to food quality, soil health and the environment. At increased concentrations, $\mathrm{Zn}$ is toxic to soil microorganisms and plants and may adversely affect soil fertility and crop yield. Current legislative frameworks for soil pollution focus predominantly on total metal content. However, environmental risks posed by heavy metals are a function not only of their overall presence in the soil, but also of their chemical speciation (Nolan et al. 2003a). It is generally accepted that the free heavy metal ion activity (Lofts et al. 2004) or solubility (McBride et al. 1997) in soil is a much better indicator of heavy metal availability in soils than that of the total heavy metal content (McBride et al. 1997; Cancés et al. 2003). This is because heavy metals in a soil solution constitute the soil metal fraction that is most directly available for plant uptake and could potentially be leached from the soil and contaminate groundwater or surface water. Many authors have shown that the activity of metal ions in the soil solution is a key factor in determination of element bioavailability and its toxicity for various organisms (Cancés et al. 2003; Degryse et al. 2009; Parker 
Table 1 Physico-chemical properties of soil

\begin{tabular}{llll}
\hline Soil particles $<0.002 \mathrm{~mm}(\%)$ & $\mathrm{pH}$ & $\mathrm{SOC}\left(\mathrm{g} \mathrm{kg}^{-1}\right)$ & $\mathrm{Zn}\left(\mathrm{mg} \mathrm{kg}^{-1}\right)$ \\
\hline 7.0 & 4.0 & 6.0 & 42.0 \\
\hline
\end{tabular}

and Pedler 1996; Weng et al. 2001). The concentration and activity of zinc in the soil solution depends on the physical and chemical properties of the soil (Ivezić et al. 2012). Several authors have indicated the increase in the total concentration of zinc in the soil solution, under the conditions of changed soil reaction into acidic, has been connected with increased solubility and mobility of this metal (Alloway 2009; McBride et al. 1997). In soil, zinc forms complexes with organic matter quite quickly, and this has a holding back effect on the activity of $\mathrm{Zn}^{2+}$ in the soil solution (Cavallaro and McBride 1984; Bar-Tal et al. 1988; Fotovat et al. 1997; Hernandez-Soriano and Jimenez-Lopez 2012). The concentration of $\mathrm{Zn}^{2+}$ in soil solution and groundwater depended on the total content of this metal as well as the value of soil pH (Nolan et al. 2003b; PérezEsteban et al. 2013).

The objective of this study is to measure the solubility of $\mathrm{Zn}$ and its speciation in solution of contaminated soils with differentiated chemical properties. In addition, these studies will allow the assessment of the possibility of predicting the solubility and speciation of $\mathrm{Zn}$ in contaminated soils from simple soil properties such as soil texture, soil $\mathrm{pH}$, total soil Zn content and soil organic matter content. This will also show which soil properties are most essential to control $\mathrm{Zn}$ speciation and mobility. The study was carried out in 2009-2011 based on the microplot field experiment located at the Experimental Station of the Faculty of Agriculture and Biology-Warsaw University of Life Sciences-SGGW, in Skierniewice (central Poland).

\section{Materials and methods}

Soil samples

The study was carried out based on the microplot field experiment located at the Experimental Station of the Faculty of Agriculture and Biology_Warsaw University of Life Sciences-SGGW, in Skierniewice (central Poland). Location of Experimental Station in Skierniewice is as follow: latitude $51^{\circ} 58^{\prime}$, longitude $20^{\circ} 10^{\prime}$, altitude $120 \mathrm{~m}$. Stoneware pots $(1.2 \mathrm{~m}$ long and $40 \mathrm{~cm}$ wide) filled with soil were treated as microplots. Experimental factors were as follows: (1) two soils with different clay particles $(<0.002 \mathrm{~mm})$ content $(7$ and $13 \%)$, (2) three levels of soil pH: 4, 5 and 6, (3) three levels of soil organic carbon (SOC): 6.0, 9.0 and $12.0 \mathrm{~g} \mathrm{C} \mathrm{kg}^{-1}$ and (4) four levels of $\mathrm{Zn}$ content in soil $\mathrm{Zn}$ : $\quad\left(42.0 \mathrm{mg} \mathrm{Zn} \mathrm{kg}^{-1}\right.$ d.m. soil, $80.0 \mathrm{mg} \mathrm{Zn} \mathrm{kg}^{-1}$ d.m. soil, $150.0 \mathrm{mg} \mathrm{Zn} \mathrm{kg}^{-1}$ d.m. soil and $320.0 \mathrm{mg} \mathrm{Zn} \mathrm{kg}^{-1}$ d.m. soil).

Researches collected soil from the control object (without fertilization) from the experimental field in Skierniewice. The main soil properties are shown in Table 1.

The addition of bentonite increased the content of clay particles. This provided two soils of different clay content: 7 and $13 \%$. These soils had differentiated $\mathrm{pH}$ value by the addition of $\mathrm{CaO}$, differentiated organic content by the addition of brown coal and differentiated zinc content by the addition of $\mathrm{ZnO}$. All soil properties were differentiated in the soil at layers of $0-30 \mathrm{~cm}$.

The conducted experiment encompassed a total of 216 microplots which formed 72 combinations of investigated factors. All factors were observed in three replications in split-plot experimental design.

\section{Analytical procedures}

Soil samples for further analyses were collected from the surface soil layer of each microplot $(0-30 \mathrm{~cm}$ deep). The soil samples were dried in the laboratory and were sieved through a sieve with a mesh of $2 \mathrm{~mm}$.

Soil samples were characterized for: $\mathrm{pH}$ - by potentiometric method after extraction with $1 \mathrm{~mol} \mathrm{dm}^{-3} \mathrm{KCl}(10 \mathrm{~g}$ of soil was suspended in $25 \mathrm{~mL}$ of $\mathrm{KCl}$ and equilibration for $24 \mathrm{~h}$ ) using a pH meter (apparatus: Schott) with a glass electrode; $\mathrm{Zn}$-after extraction in $1 \mathrm{~mol} \mathrm{dm}^{-3} \mathrm{HCl}(10 \mathrm{~g}$ of soil was shaken with $100 \mathrm{~mL} \mathrm{HCl}$ on a rotary shaker for $2 \mathrm{~h}$ at 120 rounds per minute) by inductively coupled plasma atomic emission spectrometry (ICP-AES) (apparatus: IRYS Advantage ThermoElementar); total organic carbon content - by dry combustion at high temperatures in a furnace with the collection and detection of evolved $\mathrm{CO}_{2}$ with C-MAT 5500 apparatus (Tiessen and Moir 1993); content of soil particles $<0.002 \mathrm{~mm}$-by laser diffraction method with apparatus Mastersizer 2000 (Ryżak et al. 2007).

The soil solution was obtained by modified vacuum displacement method with the use of a vacuum pump (Dynavac OP4) according to Wolt and Graveel (1986). The total concentration of zinc in soil solution was determined by inductively coupled plasma atomic emission spectrometry (ICP-AES) (apparatus: IRYS Advantage ThermoElementar). Calculations of the activity of free $\mathrm{Zn}^{2+}$ ions were performed using the software MINTEQA2 for Windows.

Statistical analysis

The results were statistically analyzed with multiple factor ANOVA, simple linear regression and multiple regression. The differences between means were detected by Tukey's 
Table 2 Total concentration ( $\mathrm{Zn})$ and activity of free ions $\left(\mathrm{Zn}^{2+}\right)$ in the soil solution according as soil properties $\left(\mathrm{mg} \mathrm{L}^{-1}\right)$

\begin{tabular}{|c|c|c|c|c|c|c|c|c|c|c|c|c|}
\hline \multirow[t]{2}{*}{ Form of $\mathrm{Zn}$} & \multicolumn{2}{|c|}{ Content of clay particles in soil } & \multicolumn{3}{|c|}{ Soil reaction $\left(\mathrm{pH}_{\mathrm{KCl}}\right)$} & \multicolumn{3}{|c|}{ SOC content in soil $\left(\mathrm{g} \mathrm{kg}^{-1}\right)$} & \multicolumn{4}{|c|}{ Content of $\mathrm{Zn}$ in soil $\left(\mathrm{mg} \mathrm{kg}^{-1}\right)$} \\
\hline & $7 \%$ & $13 \%$ & $\mathrm{pH} 4$ & pH 5 & pH 6 & 6.0 & 9.0 & 12.0 & 42.0 & 80.0 & 150.0 & 320.0 \\
\hline $\mathrm{Zn}$ & 0.37 & 0.22 & 0.58 & 0.20 & 0.09 & 0.25 & 0.29 & 0.33 & 0.18 & 0.25 & 0.34 & 0.39 \\
\hline $\mathrm{LSD}_{0.05}$ & 0.03 & & 0.03 & & & 0.11 & & & 0.06 & & & \\
\hline $\mathrm{Zn}^{2+}$ & 0.23 & 0.14 & 0.36 & 0.13 & 0.06 & 0.16 & 0.18 & 0.21 & 0.11 & 0.16 & 0.21 & 0.25 \\
\hline $\operatorname{LSD}_{0.05}$ & 0.02 & & 0.02 & & & 0.06 & & & 0.03 & & & \\
\hline
\end{tabular}

multiple-comparison test at significance level at 0.05 . Multivariate relationships were evaluated using principal component analysis (PCA). The statistical analyses were performed with Statgraphics 5.1 and Statistica 10 software.

\section{Results and discussion}

Total $\mathrm{Zn}$ concentration in soil solution

The average total zinc concentration in the soil solution ranged from 0.09 to $0.58 \mathrm{mg} \mathrm{L}^{-1}$ (Table 2). The values for zinc concentrations found in the present study are comparable with the results obtained by Rutkowska (1999) who determined zinc concentration levels in solutions of more than one hundred agricultural soils collected through out of Poland, which ranged from 0.20 to $0.46 \mathrm{mg} \mathrm{L}^{-1}$. Similar concentration values were observed by Smal et al. (2000) in forest and agricultural soils, and these ranked from 0.16 to $0.46 \mathrm{mg} \mathrm{L}^{-1}$. Lower total zinc concentrations in soil solutions were found by Sanders (1983), Curtin and Smillie (1983) as well as Gerritse et al. (1983). Stephan et al. (2008) in $0.01 \mathrm{M} \mathrm{KNO}_{3}$ solution extracts from 66 contaminated soils representative of a wide range of field conditions in both North America and Europe revealed total $\mathrm{Zn}$ concentration from 0.01 to $21.96 \mathrm{mg} \mathrm{L}^{-1}$.

The total $\mathrm{Zn}$ concentration in the soil solution was a function of the properties of the analyzed soils. Table 2 shows that the total $\mathrm{Zn}$ concentration in the soil solution decreased with increasing soil $\mathrm{pH}$ value. This is because the adsorption of $\mathrm{Zn}$ to the soil increases at higher $\mathrm{pH}$ (McBride et al. 1997; Bar-Tal et al. 1988; Msaky and Calvet 1990). It has been suggested that increases in metal retention with increasing soil $\mathrm{pH}$ may be due to adsorption, inner sphere complexation, and/or precipitation and multinuclear type reactions (Degryse et al. 2009). The solubility of $\mathrm{Zn}$ will decrease with increasing values of soil $\mathrm{pH}$. This is due to the greater adsorptive capacity of the soil solid surfaces resulting from increased $\mathrm{pH}$-dependent negative charge, the formation of hydrolyzed forms of $\mathrm{Zn}$, chemisorption on calcite and co-precipitation in Fe oxides (Alloway 2009). The soil $\mathrm{pH}$ was the factor by which the $\mathrm{Zn}$ concentration in the soil solution was most influenced. We obtained a highly significant $(p<0.0001)$ linear relationship of total $\mathrm{Zn}$ concentration in the soil solution with soil $\mathrm{pH}$ (Table 3). The linear relationship between total $\mathrm{Zn}$ concentration in the soil solution and soil $\mathrm{pH}$ alone

Table 3 Linear regression equation of $\mathrm{Zn}$ and $\mathrm{Zn}^{2+}$ concentration in soil solution $\left(\mathrm{mg} \mathrm{L}^{-1}\right)$ against soil $\mathrm{pH}$, SOC and total $\mathrm{Zn}$ content in soil

\begin{tabular}{ll}
\hline Soil $7 \%$ clay & Soil 13\% clay \\
\hline $\mathrm{Zn}( \pm 0.19)=0.88( \pm 0.08)-0.27( \pm 0.04) \mathrm{pH}$ & $\mathrm{Zn}( \pm 0.15)=0.57( \pm 0.07)-0.18( \pm 0.03) \mathrm{pH}$ \\
$r=-0.77(<0.0001)$ & $r=-0.71(<0.0001)$ \\
$\mathrm{Zn}( \pm 0.28)=0.10( \pm 0.11)+0.09( \pm 0.04)$ total $\mathrm{Zn}$ & $\mathrm{Zn}( \pm 0.19)=0.04( \pm 0.08)+0.07( \pm 0.03) \mathrm{total} \mathrm{Zn}$ \\
$r=0.37(0.0272)$ & $r=0.38(0.0211)$ \\
$\mathrm{Zn}( \pm 0.29)=0.23( \pm 0.13)+0.05( \pm 0.06) \mathrm{SOC}$ & $\mathrm{Zn}( \pm 0.20)=0.08( \pm 0.09)+0.07( \pm 0.04) \mathrm{SOC}$ \\
$r=0.15($ n.s. $)$ & $r=0.27(\mathrm{n} . \mathrm{s})$. \\
$\mathrm{Zn}{ }^{2+}( \pm 0.13)=0.52( \pm 0.06)-0.16( \pm 0.03) \mathrm{pH}$ & $\mathrm{Zn}( \pm 0.09)=0.35( \pm 0.04)-0.11( \pm 0.02) \mathrm{pH}$ \\
$r=-0.70(<0.0001)$ & $r=-0.71(<0.0001)$ \\
$\mathrm{Zn}{ }^{2+}( \pm 0.17)=0.04( \pm 0.07)+0.07( \pm 0.02) \mathrm{total} \mathrm{Zn}$ & $\mathrm{Zn}^{2+}( \pm 0.12)=0.02( \pm 0.05)+0.04( \pm 0.02) \mathrm{total} \mathrm{Zn}$ \\
$r=0.42(0.0111)$ & $r=0.41(0.0142)$ \\
$\mathrm{Zn}^{2+}( \pm 0.18)=0.12( \pm 0.08)+0.04( \pm 0.03) \mathrm{SOC}$ & $\mathrm{Zn}^{2+}( \pm 0.12)=0.08( \pm 0.05)+0.03( \pm 0.03) \mathrm{SOC}$ \\
$r=0.20($ n.s. $)$ & $r=0.20(\mathrm{n} . \mathrm{s})$. \\
\hline
\end{tabular}

The values in parentheses are the $p$ (level of significance) values, n.s. no significance for $p<0.05$ 
explains the 58.7 and $49.8 \%$ of the variability in $\mathrm{Zn}$ concentration in the soil solution for soil with 7 and $13 \%$ of clay particles, respectively.

In this study, we obtained significant linear relationship (at $p=0.05$ ) between total $\mathrm{Zn}$ concentration in the soil solution and total $\mathrm{Zn}$ content in the soil (Table 3). The content of SOC in the soil did not have the influence on total $\mathrm{Zn}$ content in the soil solution (Tables 2, 3). The results are similar to other studies which reported that $\mathrm{pH}$ was more influential than any other single property in predicting Zn solubility while SOM did not have a significant effect (McBride et al. 1997; Stephan et al. 2008, Msaky and Calvet 1990).

Stephan et al. (2008), Sauvé (2001) and McBride et al. (1997) reported that the solubility of $\mathrm{Zn}$ can be linked to both $\mathrm{H}^{+}$and the total $\mathrm{Zn}$ content in the soil. We obtained a highly significant $(p<0.001)$ relationship between the total $\mathrm{Zn}$ concentration in the soil solution and both $\mathrm{pH}$ and total soil Zn $(p<0.001)$ :

$$
\begin{aligned}
\mathrm{Zn}( \pm 0.16)= & 0.64( \pm 0.09)-0.27( \pm 0.03) \mathrm{pH} \\
& +0.09( \pm 0.02) \text { total } \mathrm{Zn} \\
R^{2}= & 72.3 \%(\text { for soil with } 7 \% \text { clay }) \\
\mathrm{Zn}( \pm 0.13)= & 0.39( \pm 0.07)-0.18( \pm 0.03) \mathrm{pH} \\
& +0.07( \pm 0.02) \text { total } \mathrm{Zn} \\
R^{2}= & 64.5 \%(\text { for soil with } 13 \% \text { clay }) .
\end{aligned}
$$

We also evaluated the potential of organic matter to influence on total $\mathrm{Zn}$ concentration in the soil solution. The soil organic matter has a dual influence on the $\mathrm{Zn}$ concentration in the soil solution. It helps adsorb $\mathrm{Zn}$ to the solid phase, therefore decreasing concentrations in soil solutions. And inversely, higher soil organic matter content will also generate higher dissolved organic carbon content, and this would help complex $\mathrm{Zn}$ and lead to higher soil solution concentrations of $\mathrm{Zn}$ (Cavallaro and McBride 1984; Bar-Tal et al. 1988; Fotovat et al. 1997; Stephan et al. 2008).

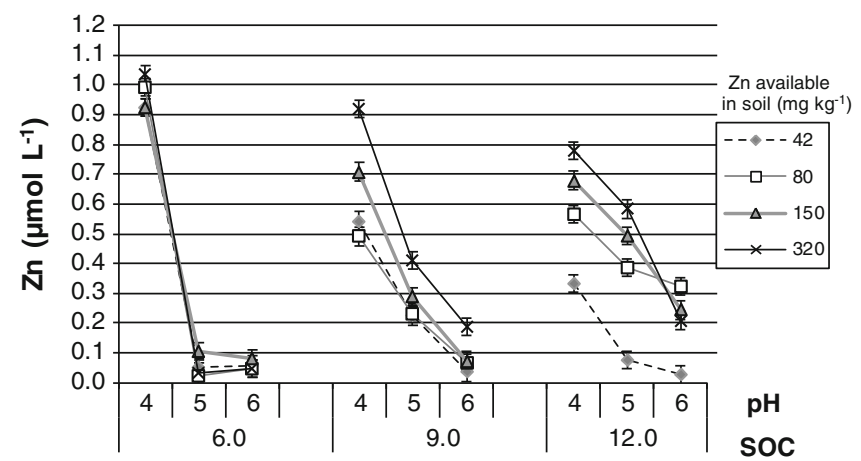

The regression of total $\mathrm{Zn}$ concentration in the soil solution was improved significantly by addition of SOC to equation $(p<0.001)$ :

$$
\begin{aligned}
\mathrm{Zn}( \pm 0.15)= & 0.54( \pm 0.11)-0.27( \pm 0.03) \mathrm{pH} \\
& +0.09( \pm 0.02) \text { total } \mathrm{Zn}+0.05( \pm 0.03) \mathrm{SOC} \\
R^{2}= & 74.5 \%(\text { for soil with } 7 \% \text { clay }) . \\
\mathrm{Zn}( \pm 0.12)= & 0.26( \pm 0.08)-0.18( \pm 0.02) \mathrm{pH} \\
& +0.07( \pm 0.02) \text { total } \mathrm{Zn}+0.07( \pm 0.02) \mathrm{SOC} \\
R^{2}= & 72.0 \% \text { (for soil with } 13 \% \text { clay }) .
\end{aligned}
$$

These relationships are shown in Fig. 1.

The soil texture also can affect the solubility of $\mathrm{Zn}$ in the soil (Dube et al. 2001; Kabata-Pendias 2004). However, the introduction of clay content into the model for $\mathrm{Zn}$ does not improve the prediction ability as shown in equation:

$$
\begin{aligned}
\mathrm{Zn}( \pm 0.14)= & 0.64( \pm 0.08)-0.21( \pm 0.02) \mathrm{pH} \\
& +0.07( \pm 0.01) \text { total } \mathrm{Zn}+0.05( \pm 0.02) \mathrm{SOC} \\
& -0.15( \pm 0.03) \text { clay content } \\
R^{2}= & 71.7 \%(p<0.001) .
\end{aligned}
$$

Principal component analysis (PCA) reviled very strong negative correlation between $\mathrm{pH}$ and $\mathrm{Zn}$ and $\mathrm{Zn}^{2+}$. Negative correlation was observed between clay and $\mathrm{Zn}$, but it was much weaker than correlation with $\mathrm{pH}$ (Fig. 2).

There was very weak correlation between SOC and $\mathrm{Zn}$. Two principal components explained about $62 \%$ of total variability (PC1 $45.7 \%$ and PC2 $16.7 \%$ ); it means that graphical presentation in Fig. 2 is enough meaningful for the evaluation of relationships between examined variables.

Solid/solution partition coefficient $\left(K_{\mathrm{d}}\right)$

The dissolution of $\mathrm{Zn}$ can be also illustrated using a simple $K_{\mathrm{d}}$ partition coefficient, which is defined as:

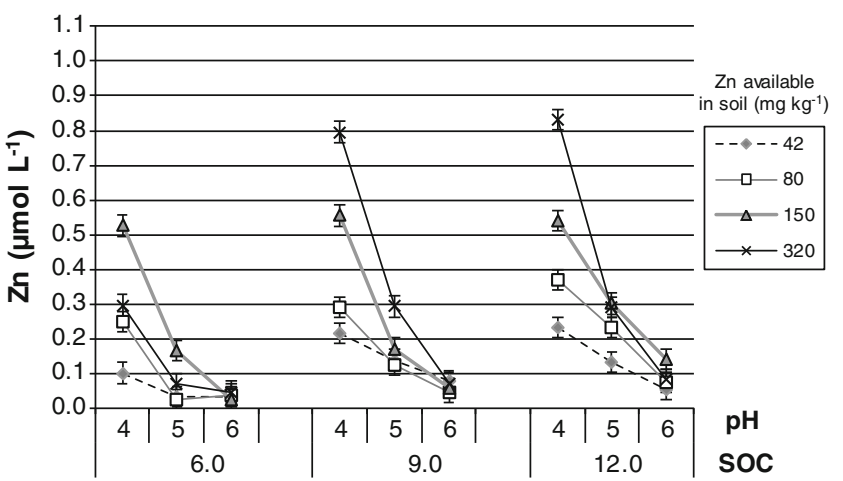

Fig. 1 The relationship between $\mathrm{Zn}$ concentration in the soil solution and soil $\mathrm{pH}$, and content of soil organic carbon content ( $\mathrm{g} \mathrm{kg}^{-1}$ soil) in different content of $\mathrm{Zn}$ available in soil 


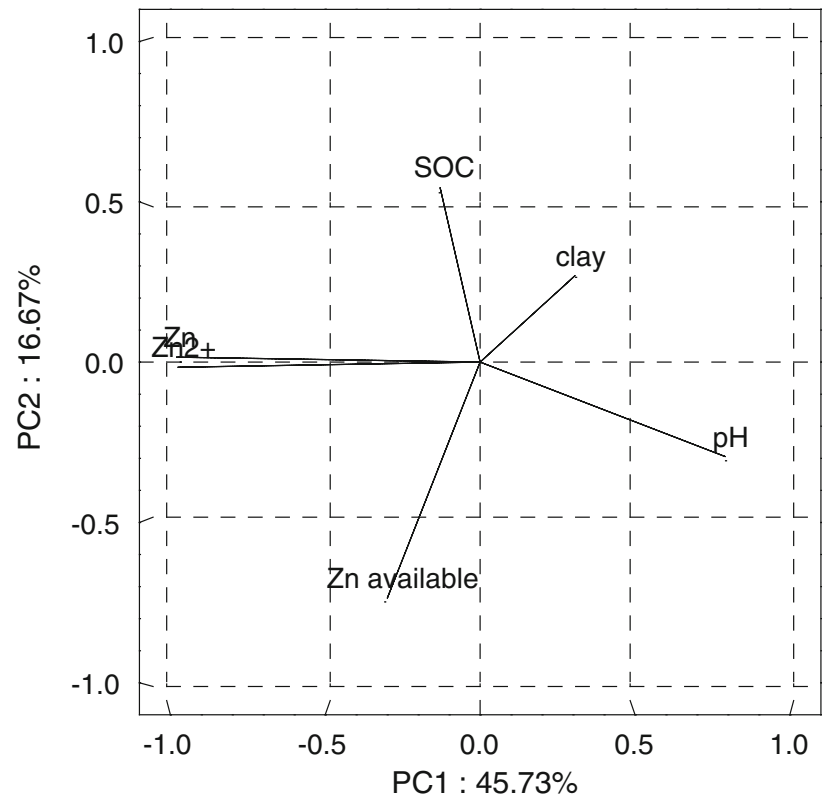

Fig. 2 Result of PCA relationship between $\mathrm{Zn}$ and environmental factors

$K_{\mathrm{d}}=($ total soil $\mathrm{Zn} /$ total dissolved $\mathrm{Zn})$

where in the present study, total soil $\mathrm{Zn}=$ soil $\mathrm{Zn}$ extracted by $1 \mathrm{~mol} \mathrm{~L}^{-1} \mathrm{HCl}$ expressed in $\mathrm{mg} \mathrm{kg}^{-1}$, and total dissolved $\mathrm{Zn}=\mathrm{Zn}$ in soil solution expressed in $\mathrm{mg} \mathrm{L}{ }^{-1}$, and the resulting $K_{\mathrm{d}}$ is in $\mathrm{L} \mathrm{kg}^{-1}$.

The partition coefficient $\left(K_{\mathrm{d}}\right)$ is usually used to describe the distribution of metal between the solid and aqueous phases in environmental risk and fate models. The coefficient can be defined as the ratio of exchangeable metal in relation to metal in soil solution (Gooddy et al. 1995), the ratio of sorbed metal to dissolved metal under equilibrium conditions (Carlon et al. 2004) or the ratio of the total soil metal relative to metal in soil water extract Krishnamurti and Naidu 2002).

The $K_{\mathrm{d}}$ values were dependent on soil properties and ranged from 166 to $2,260 \mathrm{~L} \mathrm{~kg}^{-1}$. Sauvé et al. (2000) for 298 soil samples obtained $K_{\mathrm{d}}$ values which ranging from 1.4 to $320,000 \mathrm{~L} \mathrm{~kg}^{-1}$. However, other authors obtained lower $K_{\mathrm{d}}$ values: $100-500 \mathrm{~L} \mathrm{~kg}^{-1}$ Knight et al. (1998),
17-13,100 $\mathrm{L} \mathrm{kg}^{-1}$ (Stephan et al. 2008) and 319-17,965 L kg${ }^{-1}$ (Luo et al. 2006). The differences in obtained $K_{\mathrm{d}}$ values and cited $K_{\mathrm{d}}$ values are associated with the use of different extraction solutions. The values of $K_{\mathrm{d}}$ increased significantly with rising soil $\mathrm{pH}$ and total $\mathrm{Zn}$ content and decreased with increasing soil organic content (Table 4). Observed $K_{\mathrm{d}}$ values were significantly higher in soil with $13 \%$ clay than in soil with $7 \%$ clay (Table 4 ). Also, other authors have shown a positive correlation between $K_{\mathrm{d}}$ and the soil $\mathrm{pH}$ and $\mathrm{Zn}$ content in the soil (Stephan et al. 2008; Luo et al. 2006).

Zinc speciation-free $\mathrm{Zn}^{2+}$ in soil solution

The free metal activity is recognized as a main factor in understanding metal availability in soil environment (Peijnenburg et al. 2000). It is important to measure and predict the free metal activity in soil. The preferred method is to quantify and model the contributions of different soil properties such as $\mathrm{pH}, \mathrm{Zn}$ content in soil or soil organic matter content, and then evaluate how they release to the activity of free $\mathrm{Zn}^{2+}$ in the soil solution (Sauvé 2001).

The activity of zinc free ions in the soil solution was determined using MINTEQA2 software. Estimated activity of $\mathrm{Zn}^{2+}$ ranged from 0.06 to $0.36 \mathrm{mg} \mathrm{L}^{-1}$ and was lower than the total concentration of this element in the soil solution (Table 2).

The activity of zinc in the soil solution depended on physical and chemical properties of analyzed soils (Table 2). The soil reaction was the factor by which the activity of free zinc ions was most influenced (Table 3). The activity of free $\mathrm{Zn}^{2+}$ in the solutions of analyzed soils were significantly higher at a lower value of soil $\mathrm{pH}$, which was indicated by correlation coefficients $r$ between the activity of $\mathrm{Zn}^{2+}$ in the soil solution and soil reaction $(r=-0.70)$. Tipping et al. (2003) and Tye et al. (2003) showed that soil reaction is the main factor in determining the activity of free ions and associated bioavailability. The change of soil reaction to weakly acidic or acidic results in increased activity of $\mathrm{Zn}$ in the soil solution. This is caused both by increasing solubility of chemical bonds of these elements and decreasing sorption by soil colloids at low

Table $4 \mathrm{Solid} /$ solution partition coefficient $\left(K_{\mathrm{d}}\right)$ according as soil properties $\left(\mathrm{L} \mathrm{kg}^{-1}\right)$

\begin{tabular}{|c|c|c|c|c|c|c|c|c|c|c|}
\hline \multirow[t]{2}{*}{ Form of $\mathrm{Zn}$} & \multicolumn{3}{|c|}{ Soil reaction $\left(\mathrm{pH}_{\mathrm{KCl}}\right)$} & \multicolumn{3}{|c|}{ Content of organic carbon in soil $\left(\mathrm{g} \mathrm{kg}^{-1}\right)$} & \multicolumn{4}{|c|}{ Content of $\mathrm{Zn}$ in soil $\left(\mathrm{mg} \mathrm{kg}^{-1}\right)$} \\
\hline & pH 4 & pH 5 & pH 6 & 6.0 & 9.0 & 12.0 & 42.0 & 80.0 & 150.0 & 320.0 \\
\hline Soil $7 \%$ clay & 183 & 417 & 1,234 & 404 & 379 & 352 & 166 & 230 & 376 & 685 \\
\hline $\mathrm{LSD}_{0.05}$ & 227 & & & 59 & & & 62 & & & \\
\hline Soil $13 \%$ clay & 317 & 629 & 2,260 & 1,120 & 553 & 478 & 373 & 495 & 543 & 1,036 \\
\hline $\mathrm{LSD}_{0.05}$ & 188 & & & 122 & & & 108 & & & \\
\hline
\end{tabular}



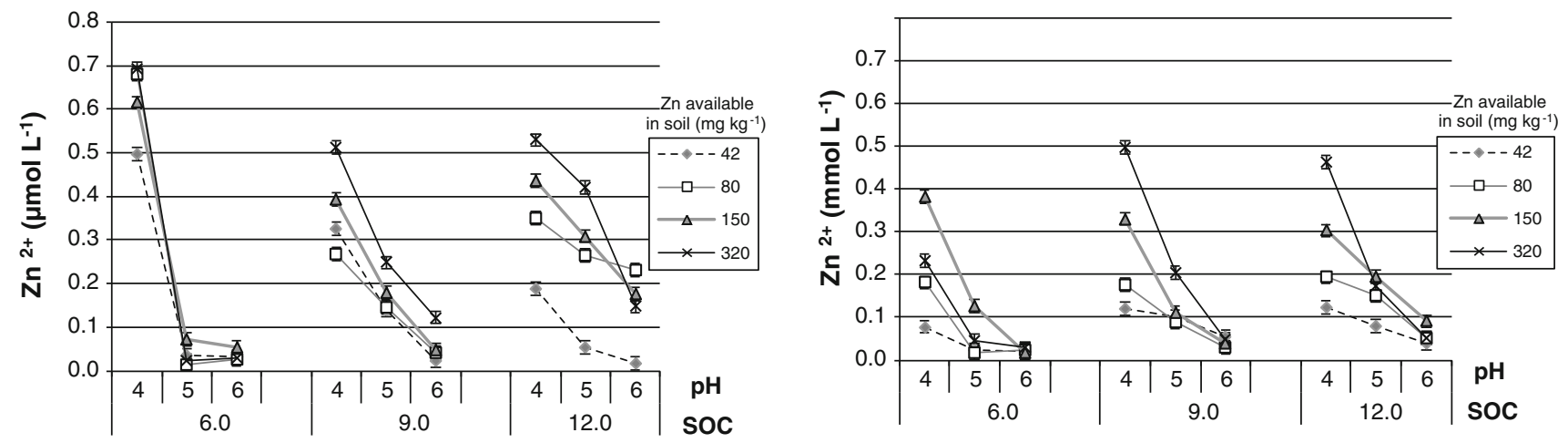

Fig. 3 The relationship between $\mathrm{Zn}^{2+}$ concentration in the soil solution and soil $\mathrm{pH}$, and the content of soil organic carbon content ( $\mathrm{g} \mathrm{kg}^{-1}$ soil) in different content of $\mathrm{Zn}$ available in soil

values of soil pH (Stephan et al. 2008). The statistical analyses showed that the activity of zinc in the soil solution was positively correlated with the content of total $\mathrm{Zn}$ in soil (Tables 2, 3). The highest concentrations of $\mathrm{Zn}^{2+}$ in the solutions of analyzed soils were observed at highest content of $\mathrm{Zn}$ in soil, and these were two times higher when compared with the solutions of not contaminated soils (Table 2). The obtained relationships are confirmed by Nolan et al. (2003b) who reported that the concentration of $\mathrm{Zn}^{2+}$ in groundwater in Australian contaminated agricultural soils depended on the total content of zinc as well as the value of soil $\mathrm{pH}$.

The $\mathrm{pH}$ and total soil $\mathrm{Zn}$ values can be combined together in order to construct a single highly significant $(p<0.001)$ predictive regression for free $\mathrm{Zn}^{2+}$ :

$$
\begin{aligned}
\mathrm{Zn}^{2+}( \pm 0.09)= & 0.48( \pm 0.07)-0.19( \pm 0.03) \mathrm{pH} \\
& +0.05( \pm 0.02) \text { total } \mathrm{Zn} \\
R^{2}= & 63.5 \%(\text { for soil with } 7 \% \text { clay }) \\
\mathrm{Zn}^{2+}( \pm 0.06)= & 0.24( \pm 0.04)-0.11( \pm 0.01) \mathrm{pH} \\
& +0.04( \pm 0.01) \text { total } \mathrm{Zn} \\
R^{2}= & 65.5 \%(\text { for soil with } 13 \% \text { clay }) .
\end{aligned}
$$

The regression between free $\mathrm{Zn}^{2+}$ concentration in soil solution and total soil $\mathrm{Zn}$ content (Table 3) was improved significantly by the addition of $\mathrm{pH}$ to equation.

The activity of zinc increased with increasing contents of soil organic carbon; however, such relationship was not statistically significant (Tables 2,3 ). Increasing content of SOC can increase the formation of organic metal complexes, while the solubility of metals may also increase (Aldrich et al. 2002). The introduction of soil organic carbon into the model for free $\mathrm{Zn}^{2+}$ improves the prediction ability from 63.5 to $71.3 \%$ (soil with $7 \%$ clay) and from 65.5 to $70.9 \%$ (soil with $13 \%$ clay) as shown in equations $(p<0.001)$ :

$$
\begin{aligned}
\mathrm{Zn}^{2+}( \pm 0.07)= & 0.18( \pm 0.05)-0.11( \pm 0.03) \mathrm{pH} \\
& +0.09( \pm 0.02) \text { total } \mathrm{Zn}+0.05( \pm 0.03) \mathrm{SOC} \\
R^{2}= & 71.3 \%(\text { for soil with } 7 \% \text { clay }) . \\
\mathrm{Zn}^{2+}( \pm 0.07)= & 0.26( \pm 0.07)-0.16( \pm 0.02) \mathrm{pH} \\
& +0.07( \pm 0.01) \text { total } \mathrm{Zn}+0.04( \pm 0.02) \mathrm{SOC} \\
R^{2}= & 70.9 \% \text { (for soil with } 13 \% \text { clay }) .
\end{aligned}
$$

These relationships are shown in Fig. 3 .

Soil texture had rather small effects on the activity of zinc in the soil solution (Tables 2, 3). Correlation coefficients indicated only weak relationships between clay content in soil and free $\mathrm{Zn}^{2+}$ in the soil solution. However, the results of statistical analysis (ANOVA) showed significantly higher total concentrations of free zinc ions in the soil solution of sandy soil (7\% clay) when compared with those of medium soils (13\% clay). Medium soils are characteristic of higher capacity of the sorption complex, and therefore, smaller amounts of zinc are released into the soil solution. On the other hand, in solutions of sandy soils-with lower capacity of the sorption complex-there are more $\mathrm{Zn}$ in their active forms. According to Rutkowska et al. (2006), the level of ion concentration in the soil solution depends on soil granulometric composition, and the concentration of $\mathrm{Zn}$ in the solutions of sandy soils is usually higher than in the solutions of soils with higher content of clay particles. The introduction of clay content into the model for $\mathrm{Zn}^{2+}$ does not improve the prediction ability as shown in equation:

$$
\begin{aligned}
\mathrm{Zn}^{2+}( \pm 0.06)= & 0.37( \pm 0.06)-0.13( \pm 0.01) \mathrm{pH} \\
& +0.05( \pm 0.009) \text { total } \mathrm{Zn}+0.04( \pm 0.01) \mathrm{SOC} \\
& -0.09( \pm 0.02) \text { clay content } \\
R^{2}= & 68.9 \%(p<0.001) .
\end{aligned}
$$




\section{Conclusion}

The results of the present study showed that physicalchemical soil properties significantly differentiated the value of the $K_{\mathrm{d}}$ coefficient, the total concentration of zinc and the activity of free zinc ions in the soil solution. The activity of free $\mathrm{Zn}^{2+}$ in the soil solutions is very high and ranges from 64 to $68 \%$ of the total $\mathrm{Zn}$ concentration in the soil solution. Soil reaction is the factor with the highest influence on the total concentration and activity of zinc free ions in the soil solution. The total concentration and activity of zinc free ions in the soil solutions increase significantly with rising soil acidity. The risk of contamination of soils and crops with zinc increases under the conditions of soils which are sandy, acidic and deficient in organic matter. Solid/solution partition coefficient $\left(K_{\mathrm{d}}\right)$ and multiple regression analysis of total $\mathrm{Zn}$ and free $\mathrm{Zn}^{2+}$ concentration in soil solution versus soil properties such as soil $\mathrm{pH}$, total $\mathrm{Zn}$ content and soil organic carbon (SOC) content have been successfully used to predict the $\mathrm{Zn}$ mobility in soil and environmental risks in contaminated soils.

Acknowledgments This study was conducted as a partial fulfillment of doctor degree in Agriculture Chemistry Department, Warsaw University of Life Sciences, Poland, supported by the Ministry of Science and Higher Education of Poland, Project No. 2 P06R 02629.

\section{References}

Aldrich AP, Kistler D, Sigg L (2002) Speciation of $\mathrm{Cu}$ and $\mathrm{Zn}$ in drainage water from agricultural soils. Environ Sci Technol 36:4824-4830

Alloway BJ (2009) Soil factors associated with zinc deficiency in crops and humans. Environ Geochem Health 31:537-548

Bar-Tal A, Baryosef B, Chen Y (1988) Effects of fulvic acid and pH on zinc sorption on montmorillonite. Soil Sci 146:367-373

Cancés B, Ponthieu M, Castrec-Pouelle M, Aubry E, Benedetti MF (2003) Metal ions speciation in a soil and its soil solution: experimental data and model results. Geoderma 113:341-355

Carlon C, Valle MD, Marcomini A (2004) Regression models to predict water-soil heavy metals partition coefficients in risk assessment studies. Environ Pollut 127:109-115

Cavallaro N, McBride MB (1984) Zinc and copper and fixation by an acid soil clay: effect of selective dissolutions. Soil Sci Soc Am J 48:1050-1054

Curtin D, Smillie GW (1983) Soil solution composition as affected by liming and incubation. Soil Sci Soc Am J 47:701-707

Degryse F, Smolders E, Parker DR (2009) Partitioning of metals (Cd $\mathrm{Co}, \mathrm{Cu}, \mathrm{Ni}, \mathrm{Pb}, \mathrm{Zn}$ ) in soils: concepts, methodologies, prediction and applications-a review. Eur J Soil Sci 60(5):90-612

Dube A, Zbytniewski R, Kowalkowski T, Cukrowska E, Buszewski B (2001) Adsorption and migration of heavy metals in soil. Pol J Environ Stud 10(1):1-10

Fotovat A, Naidu R, Sumner ME (1997) Water: soil ratio influences aqueous phase chemistry of indigenous copper and zinc in soils. Aust J Soil Res 35:687-709

Gerritse RG, Van Driel W, Smilde KW, Van Luit B (1983) Uptake of heavy metals by crops in relation to their concentration in the soil solution. Plant Soil 75:393-404
Gooddy DC, Shand P, Kinniburgh DC, Van Riemsdijk WH (1995) Field-based partition coefficients for trace elements in soil solutions. Eur J Soil Sci 46:265-285

Hernandez-Soriano MC, Jimenez-Lopez JC (2012) Effects of soil water content and organic matter addition on the speciation and bioavailability of heavy metals. Sci Total Environ 423:55-61

Ivezić V, Almås AR, Singh BR (2012) Predicting the solubility of Cd, $\mathrm{Cu}, \mathrm{Pb}$ and $\mathrm{Zn}$ in uncontaminated Croatian soils under different land uses by applying established regression models. Geoderma 170:89-95

Kabata-Pendias A (2004) Soil-plant transfer of trace elements-an environmental issue. Geoderma 122:143-149

Knight BP, Chaudri AM, McGrath SP, Giller KE (1998) Determination of chemical availability of cadmium and zinc in soils using inert soil moisture samplers. Environ Pol 99:293-298

Krishnamurti GSR, Naidu R (2002) Solid-solution speciation and phytoavailability of copper and zinc in soils. Environ Sci Technol 36:4386-4391

Lofts S, Spurgeon DJ, Svendsen C, Tipping E (2004) Deriving soil critical limits for $\mathrm{Cu}, \mathrm{Zn}, \mathrm{Cd}$, and $\mathrm{pH}$ : a method based on free ion concentrations. Environ Sci Technol 38:3623-3631

Luo X-S, Zhou D-M, Liu X-H, Wang Y-J (2006) Solid/solution partitioning of heavy metals in the contaminated agricultural soils around a copper mine in eastern Nanjing city, China. J Hazard Mater 131:19-27

McBride M, Sauvé S, Hendershot W (1997) Solubility control of Cu, $\mathrm{Zn}, \mathrm{Cd}$ and $\mathrm{Pb}$ in contaminated soils. Eur J Soil Sci 48:337-346

Msaky JJ, Calvet R (1990) Adsorption behaviour of copper and zinc in soils: influence of $\mathrm{pH}$ on adsorption characteristics. Soil Sci 150:513-522

Nolan AL, Lombi E, McLaughlin MJ (2003a) Metal bioaccumulation and toxicity in soils - why bother with speciation? Aust J Chem 56:77-91

Nolan AL, McLaughlin MJ, Mason SD (2003b) Chemical speciation of $\mathrm{Zn}, \mathrm{Cd}, \mathrm{Cu}$, and $\mathrm{Pb}$ in pore waters agricultural and contaminated soils using Donnan dialysis. Environ Sci Technol 37:90-98

Parker DR, Pedler JF (1996) Reevaluation of the free-ion activity model of trace metal availability to higher plants. Plant Soil 196:223-228

Peijnenburg W, Baerselman R, de Groot A, Jager T, Leenders D, Posthuma L, Van Veen R (2000) Quantification of metal bioavailability for lettuce (Lactuca sativa $\mathrm{L}$.) in field soils. Arch Environ Contam Toxicol 39:420-430

Pérez-Esteban J, Escolástico C, Moliner A, Masaguer A (2013) Chemical speciation and mobilization of copper and zinc in naturally contaminated mine soils with citric and tartaric acids. Chemosphere 90:276-283

Rutkowska B (1999) The concentration of micronutrients in the soil solution in different soil and fertilizer conditions. PhD thesis. Warsaw University of Life Sciences

Rutkowska B, Szulc W, Łabętowicz J (2006) Granulometric composition of soil as a factor determining the concentration of ions in soil solution. J Elementol 11(1):89-98

Ryżak M, Bieganowski A, Walczak RT (2007) Application of laser diffraction method for determination of particle size distribution of grey-brown podzolic soil. Res Agric Eng 53(1):34-38

Sanders JR (1983) The effect of $\mathrm{pH}$ on the total and free ionic concentrations of manganese, zinc and cobalt in soil solutions. J Soil Sci 34:315-323

Sauvé S (2001) Speciation of metals in soils. In: Allen HE (ed) Bioavailability of metals in terrestrial ecosystems: importance of partitioning for bioavailability to invertebrates, microbes and plants. SETAC Press, Pensacola, Florida, pp 7-58

Sauvé S, Hendershot W, Allen HE (2000) Solid-solution partitioning of metals in contaminated soils: dependence on $\mathrm{pH}$, total metal burden, and organic matter. Environ Sci Tech 34:1125-1131 
Smal H, Ligęza S, Misztal M (2000) The total content of $\mathrm{Zn}, \mathrm{Cu}, \mathrm{Pb}$ and $\mathrm{Cd}$ in soil and soil solution in the profiles of arable and forest soils. Adv Agric Sci Probl Issues 471:1117-1124

Stephan CH, Courchesne F, Hendershot WH, McGrath SP, Chaudri AM, Sappin-Didier V, Sauve S (2008) Speciation of zinc in contaminated soils. Environ Pollut 155(2):208-216

Tiessen H, Moir JO (1993) Total and organic carbon. In: Carter ME (ed) Soil sampling and methods of analysis. Lewis Publishers, Ann Arbor, pp 187-211

Tipping E, Rieuwerts J, Pan G, Ashmore MR, Lofts S, Hill MTR, Farago ME, Thornton I (2003) The solid-solution partitioning of heavy metals $(\mathrm{Cu}, \mathrm{Zn}, \mathrm{Cd}, \mathrm{Pb})$ in upland soils of England and Wales. Environ Pollut 125:213-225
Tye AMS, Young D, Crout NMJ, Zhang H, Preston S, BarbosaJefferson VL, Davison W, McGrath SP, Paton GI, Kilham K, Resende L (2003) Predicting the activity of $\mathrm{Cd}^{2+}$ and $\mathrm{Zn}^{2+}$ in soil pore water from the radio-labile metal fraction. Geochim Cosmochim Acta 67:375-385

Weng L, Temminghoff EJ, Van Riemsdijk WH (2001) Determination of the free ion concentration of trace metals in soil solution using a soil column Donnan membrane technique. Eur J Soil Sci 52:629-637

Wolt JD, Graveel J (1986) A rapid routine method for obtaining soil solution using vacuum displacement. Soil Sci Soc Am J 50:602-605 